\title{
PERUBAHAN JUMLAH KONSUMEN RITEL TRADISIONAL SETELAH ADANYA RITEL MODEREN DI KECAMATAN SUMBAWA
}

\author{
Ryan Suarantalla ${ }^{1}$, Mely Awatifa Nur ${ }^{2}$, Koko Hermanto ${ }^{3^{*}}$, \\ ${ }^{1 *}$ Fakultas Teknik Universitas Teknologi Sumbawa \\ ${ }^{2}$ Fakultas Teknik Universitas Teknologi Sumbawa \\ ${ }^{3}$ Fakultas Teknik Universitas Teknologi Sumbawa \\ *Corresponding Author email: ryan.suarantalla@uts.ac.id, koko.hermanto@uts.ac.id
}

\begin{tabular}{|c|c|}
\hline \multirow{5}{*}{$\begin{array}{l}\text { Diterima } \\
\text { Bulan September } \\
2020\end{array}$} & Abstrak \\
\hline & Di kecamatan Sumbawa, provinsi Nusa Tenggara Barat (NTB) sekarang ini telah \\
\hline & banyak berdiri toko-toko ritel moderen (Indomaret, Alfamart). Akan tetapi terdapat \\
\hline & kecamatan-kecamatan lain di provinsi NTB melarang ritel moderen untuk beroprasi, \\
\hline & pengaruh bagi keberadaan toko kelontong (ritel \\
\hline & tradisional). Oleh karena itu tujuan dari penelitian ini adalah menganalisis apakah ada \\
\hline Diterbitkan & perubahan jumlah konsumen pada ritel tradisional sebelum dan setelah adanya ritel \\
\hline Bulan Oktober & moderen di kecamatan Sumbawa. Adapun sampel yang digunakan pada penelitian ini \\
\hline 2020 & adalah penduduk kecamatan Sumbawa. Penelitian ini menggunakan pendekatan \\
\hline & $\begin{array}{l}\text { kuantitatif dengan analisis statistika. Data yang digunakan pada penelitian ini adalah } \\
\text { data primer, yaitu diperoleh melalui penyebaran kuesioner pada sampel. Diketahui }\end{array}$ \\
\hline Keyn & jumlah penduduk kecamatan Sumbawa berdasarkan data Badan Statistika Kabupaten \\
\hline Ritel Moderen, & Sumbawa tahun 2018 adalah 61.518 orang, sehingga dengan menggunakan rumus \\
\hline Ritel Tradisiona & Slovin banyaknya sampel yang harus ikut kuesioner untuk penelitian ini adalah minimal \\
\hline $\begin{array}{l}\text { Jumlah Pelangan, } \\
\text { Uii Tanda. Non }\end{array}$ & 100 orang (dengan tingkat error $10 \%$ ) yang dipilih secara random sampling. Metode \\
\hline $\begin{array}{l}\text { Ujl Ianda, Non } \\
\text { Parametrik }\end{array}$ & $\begin{array}{l}\text { an untuk mencapai tujuan penelitian ini adalah menggunakan Uji Tanda } \\
\text { SPSS. Hasil analisa menunjukkan bahwa keberadaan ritel moderen di }\end{array}$ \\
\hline & an Sumbawa menurunkan jumlan konsumen yang belanja di ritel tradisional. \\
\hline
\end{tabular}

\section{PENDAHULUAN}

Persaingan bisnis di dalam dunia usaha mengharuskan setiap pembisnis agar dapat tetap bertahan dalam mengembangkan usahanya, hal ini dikarenakankan keperluan konsumen yang semakin beragam oleh karena itu para pebisnis harus pintar dalam menerapkan strategi untuk menarik konsumen. Usaha kecil adalah salah satu pelaku bisnis yang turut serta di dalam persaingan ini. Salah satu persaingan yang pasti di hadapi oleh pebisnis kecil adalah, pesatnya pembangunan pasar modern yang telah banyak dirasakan oleh banyak pihak berpengaruh terhadap keberadaan pasar tradisional yang sebagian besar adalah usaha kecil perorangan atau ritel tradisional. Di salah satu sisi, pasar modern telah dikelola secara professional serta fasilitas yang disediakan serba lengkap. Di sisi lain ritel tradisional masih disibukkan dengan permasalahan-permasalahan klasik seputar pengelolaan yang masih kurang profesional serta ketidak nyamanan fasilitas dalam berbelanja. Pasar modern dan pasar tradisional bersaing pada pasar yang sama, yaitu pasar ritel. Dimana hampir semua produk yang dijual pada pasar tradisional umumnyanya dapat ditemui di pasar modern, khususnya hypermarket. Bisnis ritel memang dinilai prospektif sehingga menimbulkan persaingan yang luar biasa, persaingan lain yang juga dapat menjadi permasalahan baru bagi pelaku usaha kecil (kali ini toko-toko) yaitu pesatnya pertumbuhan minimarket dengan sistem waralaba yang juga bersaing pangsa pasar yang sama yakni pasar ritel (Rusno, 2008).

Penjualan eceran atau ritel dengan pola tradisional merupakan salah satu contoh sektor informal dalam bidang perdagangan yang kerap di temui di Kota Sumbawa, khususnya di daerah pedesaan. Karakteristik pemilik usaha ini pada umumnya digambarkan memiliki tingkat pendidikan yang rendah dan modal yang kecil, yang sebelumnya tidak mampu menangkap peluang bekerja di sektor formal, sehingga harus membuka lapangan pekerjaan bagi diri sendiri. Jenis usaha seperti ini menjajakan barang-barang konsumsi secara langsung kepada konsumen, tanpa melalui proses perubahan bentuk sebelumnya.

Ritel tradisional yang hanya memiliki kekuatan internal tanpa proteksi dari pihak eksternal manapun, kini menghadapi persaingan yang lebih sulit ketika dihadapkan dengan pendirian ritel yang berkonsep modern di perkotaan, yang menjajakan produk serupa dengan produk yang tersedia di retail tradisional, bahkan dengan diferensiasi produk lebih lengkap dan dengan kondisi dan penataan toko yang lebih rapi. Ritel dengan konsep modern ini kemudian mampu 
menarik lebih banyak minat masyarakat untuk berbelanja daripada ritel konsep tradisional. Hal ini tentu saja memberikan dampak dan pengaruh baik secara langsung maupun tidak langsung terhadap keberadaan ritel tradisional.

Indomaret dan Alfamart adalah contoh ritel modern berkonsep franchise yang banyak di temui di kota Sumbawa, bahkan saat ini sudah menyebar hingga ke daerah pedesaan. Ritel ini pada umumnya memiliki ruang yang tidak terlalu besar namun telah memiliki sistem manajemen dan diferensiasi produk yang cukup baik. Dengan esensi merk serta promo yang gencar dilakukan oleh manajemennya, ritel ini sangat diterima baik oleh masyarakat di daerah kota. Permasalahan muncul karena produk yang ditawarkan oleh ritel Indomaret/Alfamart pada umumnya identik dengan produk yang ditawarkan oleh ritel tradisional. Dengan berbagai kelebihan berupa diferensiasi produk dan kenyamanan toko yang ditawarkan oleh ritel Indomaret/Alfamart, maka penduduk perkotaan memiliki persepsi untuk lebih menyukai berbelanja di ritel Indomaret/Alfamart daripada di ritel tradisional. Hal ini akan mengurangi kemampuan ritel tradisonal dalam menjangkau pelanggan. Ketidakberdayaan ritel tradisional sebagai sektor informal serta semakin maraknya pendirian ritel Indomaret/Alfamart di kota Sumbawa tentu saja mengakibatkan berbagai dampak terhadap keberlangsungan ritel tradisional tersebut.

Persaingan antara ritel tradisional dan ritel modern banyak mengundang perhatian segala kalangan, dikarenakan selalu menempatkan pihak ritel tradisional dalam tingkat yang lemah. Perbedaan karakteristik yang berbanding terbalik dengan semakin memperlemah keadaan ritel tradisional. Ketidakjelasan regulasi mengenai industri ritel, menambah berat upaya untuk melindungi ritel tradisional. Ruang lingkup persaingan antara ritel tradisional dan ritel modern meliputi faktor internal maupun faktor eksternal, yaitu meliputi keseluruhan atribut di dalam aspek kinerja, aspek preferensi konsumen, dan aspek regulasi. Aspek preferensi konsumen mencakup human resource (terkait pelayanan yang diberikan), merchandise, harga dan lokasi (Utomo, 2011).

Peran serta pemerintah sangat penting dalam mengatasi masalah yang tengah dihadapi oleh ritel tradisional agar kinerja parapedagang kecil tidak mengalami penurunan diantaranya melakukan penertiban terhadap pendirian geraigerai minimarket khususnya Indomaret dan Alfamart. Sebagaimana terlampir pada Perpres No. 112/2007 tentang penataan dan pembinaan pasar tradisional pusat perbelanjaan dan toko modern, sebagaimana yang terdapat pada pasal 1 ayat 12 yang tentang peraturan zona, yang diharapkan mampu melindungi pedagang tradisional. Begitu juga halnya yang terdapat dalam Undang-Undang No. 9 tahun 1995 tentang usaha kecil dalam pasal 8 disebutkan bahwa pemerintah harus menjaga iklim usaha dalam kaitannya dengan persaingan, dengan membuat peraturanperaturan yang diperlukan. Untuk melindungi usaha kecil, pemerintah mencegah terjadinya penguasaan pasar dan pemusatan usaha oleh orangperseorangan ataukelompok tertentu yang merugikan usaha kecil.

Berdasarkan pemaparan di atas maka peneliti mencoba untuk mengkaji analisis perubahan jumlah konsumen pada ritel tradisional setelah adanya ritel modern di kecamatan Sumbawa. Penelitian tentang analisa keberadaan ritel moderen pernah dilakukan oleh Amri pada tahun 2017, dimana pada penelitian tersebut dianalisis perbandingan jumlah laba pedagang kelontong setelah adanya ritel moderen adapun metode statistika yang digunakan adalah uji t, diperoleh hasil penelitian bahwa keuntungan (labah) yang diperoleh oleh warung kelontong mengalami penurunan. Serta penelitian yang dilakukan oleh Hermanto dan Suarantalla pada tahun 2020, pada penelitian tersebut populasinya adalah mahasiswa program studi Teknik Industri Universitas Teknologi Sumbawa digunakan untuk menganalisa apakah terdapat perubahan minat belanja mahasiswa mahasiswa Teknik Industri dianalisis menggunakan uji Wilcoxon, dari hasil penelitian diperoleh bahwa tidak ada perubahan minat mahasiswa program studi Teknik Industri Universitas Teknologi Sumbawa berbelanja pada ritel tradisional setelah adanya ritel moderen di sekitar kampus.

\section{LANDASAN TEORI}

Ritel tradisional bersifat sederhana, tempatnya tidak terlalu luas, barang yang dijual tidak terlalu banyak jenisnya, sistem pengelolaan/manajemennya masih sederhana, tidak menawarkan kenyamanan berbelanja dan masih ada proses tawar-menawar harga dengan pedagang, serta produk yang dijual tidak dipajang secara terbuka sehingga pelanggan tidak mengetahui apakah peritel memiliki barang yang dicari atau tidak. Ritel modern menawarkan tempat yang luas, barang yang dijual banyak jenisnya, sistem manajemen terkelola dengan baik, menawarkan kenyamanan berbelanja, harga jual sudah tetap (fixed price) sehingga tidak ada proses tawarmenawar dan adanya sistem swalayan/pelayanan mandiri, serta pemajangan produk pada rak terbuka sehingga pelanggan bisa melihat dan memilih 
terlebih dahulu sebelum memutuskan untuk membeli (Sihombing \& Hidayat, 2013).

Dalam memulai sebuah usaha ritel, tidak harus selalu dilakukan secara individu, tetapi bisa dengan menggunakan sistem yang sudah ada, salah satunya dengan sistem waralaba. Dengan menggunakan sistem ini, peritel tidak perlu memikirkan usaha ritel apa yang akan dijalankan. Peritel hanya perlu membeli hak waralaba, dan usaha ritel pun bisa dengan segera dilaksanakan. yang dimaksudkan dengan waralaba ialah suatu sistem pendistribusian barang atau jasakepada pelanggan akhir, dimana pemilik merek (franchisor) memberikan hak kepada individu atau perusahaan (franchisee) untuk melaksanakan bisnis dengan merek, nama, sistem, prosedur, dan caracara yang telah ditetapkan sebelumnya dalam jangka waktu tertentu dan meliputi area tertentu. Membeli franchise adalah cara yang aman untuk memulai dan menjalankan suatu usaha. Franchisee tidak sepenuhnya bebas, dan dengan adanya bimbingan dari franchisor dalam hal pemilihan lokasi dan dekorasi interior, serta dukungan selama operasi maka franchisee tidak akan membuat kesalahan, yang mungkin harus dibayar mahal, sebanyak kalau memulai usaha sendiri secara independen (Sihombing \& Hidayat, 2013).

Perilaku konsumen adalah proses pengambilan keputusan yang mensyaratkan aktivitas individu untuk mengevaluasi, memperoleh, menggunakan atau mengatur barang dan jasa. Dari berbagai definisi tersebut, dapat ditarik kesimpulan bahwa perilaku konsumen menyoroti perilaku baik individu maupun rumah tangga, perilaku konsumen menyangkut suatu proses pengambilan keputusan sebelum pembelian sampai dengan mengkonsumsi produk, dan tujuan mempelajari perilaku konsumen adalah untuk menyusun strategi pemasaran yang berhasil. Perilaku Konsumen Perilaku (behavior) pada hakikatnya merupakan tindakan nyata konsumen yang dapat diobservasi secara langsung (Andespa, 2016).

Atribut yang mempengaruhi konsumen dalam memilih tempat belanja Konsumen biasanya mendatangi tempat berbelanja dengan tujuan dan motif serta pertimbangan yang bermacam-macam. Dalam memilih toko, konsumen dapat melakukan penilaian terhadap atribut-atribut yang mempengaruhi mereka dalam memilih tempat berbelanja. Menurut Budiani pada 2015 atributatribut yang mempengaruhi konsumen dalam memilih tempat berbelanja:
1. Harga
2. Lokasi
3. Sifat dan kualitas keragaman barang
4. Iklan dan Promosi
5. Personel Penjualan
6. Pelayanan yang Diberikan

7. Atribut Fisik Toko

8. Atmosfer Toko

Uji tanda merupakan metode Statistika yang digunakan dalam penelitian ini. Uji tanda merupakan uji nonparametrik yang digunakan untuk menguji ada tidaknya perbedaan dari dua buah populasi yang saling berpasangan. Uji tanda bertujuan untuk mempelajari suatu perbedaan tanpa mengukur besar perbedaannya. Uji tanda digunakan untuk menguji perbedaan dua sampel tak bebas (Dependent). Esensi dari uji tanda terletak pada arah perbedaan (positif atau negatif), bukan pada besarnya perbedaan-perbedaan tersebut.

\section{MATODE PENELITIAN}

\section{Pendekatan Penelitian}

Penelitian ini termasuk jenis penelitian kuantitatif, penelitian kuantitatif adalah penelitian yang datanya dinyatakan dalam angka dan dianalisis dengan teknik statistik.

\section{Populasi dan Sampel}

Populasi dalam penelitian ini adalah warga atau masyarakat yang tinggal di kecamatan Sumbawa. Berdasarkan jumlah warga kecamatan Sumbawa di Badan Statistika Kabupaten Sumbawa adalah 61.518 jiwa. Karena populasi pada penelitian ini diketahui maka pengambilan sampel penelitian menggunakan metode solvin (Pradana \& Reventiary, 2016), yaitu menggunakan persamaan (1) sebagai berikut.

$$
n=\frac{N}{1+N e^{2}}
$$

Keterangan

$n \quad=$ ukuran sampel

$N \quad=$ ukuran popolasi

$e \quad=$ persen kelonggaran ketidak pastian

Penelitian ini menggunakan tingkat keyakinan $90 \%$ karena menggunakan tingkat ketidakpastian sebesar $10 \%$. Apabila dilakukan perhitungan menggunakan persamaan (1) maka jumlah minimum sampel penelitian adalah minimal 100 responden. penelitian ini:

Berikut merupakan kriteria populasi pada

1. Kawasan Kecamatan Sumbawa.

2. Tempat tinggal tidak jauh dengan ritel tradisional dan ritel moderen.

\section{Teknik Pengumpulan Data}

Pengambilan Sampel dalam penelitian menggunakan penarikan data dengan cara memberikan kuisioner (angket) kepada masyarakat kecamatan Sumbawa. Adapun pertanyaan yang diberikan dalam form kusioner adalah berapa kali masing-masing masyarakat kecamatan Sumbawa 
berbelanja pada ritel tradisional sebelum dan setelah adanya ritel moderen (Alfamart/Indomaret) dalam sebulan.

\section{Defenisi Operasional}

Variabel penelitian adalah segalah sesuatu yang berbentuk apa saja yang ditetapkan oleh peneliti untuk dipelajari sehingga diperoleh informasi tentang hal tersebut, kemudian ditarik kesimpulannya. Berikut adalah definisi operasional dari variabel yang akan diteliti.

1. Ritel Modern Ritel modern merupakan pasar yang dikelola dengan manajemen modern, umunya terdapat dikawasan perkotaan sebagai penyedia barang dan jasa dengan mutu dan pelayanan yang baik kepada konsumen seperti mall, supermarket, minimarket, swalayan, pasar serba ada, waralaba, department store, shopping centre dan sebagainya.

2. Toko kelontong (ritel tradisional) yaitu toko yang dikelola masyarakat tertentu dan biasanya dengan modal yang kecil, dan dikelolah dengan manajemen sederhana

Sedangkan variabel pada penelitian ini adalah frekuensi masing-masing masyarakat kecamatan Sumbawa berbelanja pada ritel tradisional sebelum dan setelah adanya ritel moderen (Alfamart/Indomaret) dalam sebulan.

\section{Teknik Analisis Data}

Pengelolahan data hasil kuisioner untuk mengetahui perubahan konsumen ritel tradisional setelah adanya ritel moderen adalah menggunakan metode komputerisasi yaitu menggunakan SPSS, terlebih dahulu dilakukan uji normalitas.Apabila data tersebut tidak berdistribusi normal, makadilakukan uji tanda untuk menguji hipotesis. Adapun langkah-langkah manual uji tanda adalah sebagai berikut (Kadir, 2015):

1. Menyatakan hipotesis statistik Hipotesis nol dalam penelitian ini adalah banwa dengan adanya ritel moderen tidak memengaruhi jumlah pelanggan yang datang ke ritel tradisional. Tanda negatif menunjukkan penurunan jumlan pelangan. Jika hipotes alternatitnya dinyatakan sebagai uji pihak kiri, yaitu "Keberadaan ritel moderen di kecamatan Sumbawa menurunkan jumlah pelanggan yang belanja di ritel tradisional" Misalkan penurunan kurang dari $50 \%$.

Hipotesis statistik:

$H_{0}: P \geq 0,5$

$H_{a}: P<0,5$

2. Menentukan Taraf signifikan, misalkan diambil $\alpha=0,05$

3. Menentukan probabilitas hasil sampel.
Misalkan $p$ adalah proposisi penurunan jumlah pelangan dalam sampel, maka

$\mu_{p}=p$ dan $\sigma_{r}=\sqrt{\frac{p(1-p)}{n}}$ sehingga $Z=$ $\frac{p_{i}-\mu_{i}}{\sigma_{p}}$

4. Membuat kesimpulan

Terima $H_{0}$ jika $\alpha \leq$ probabilitas hasil sampel.

\section{HASIL DAN PEMBAHASAN}

\section{Uji Statistika Deskriptif}

Data hasil kuisioner pada 100 responden sebagai sampel penelitian tentang perubahan jumlah konsumen ritel tradisional setelah adanya ritel moderen di kecamatan Sumbawa disajikan dalam bentuk grafik seperti pada gambar 1, sebagai berikut.

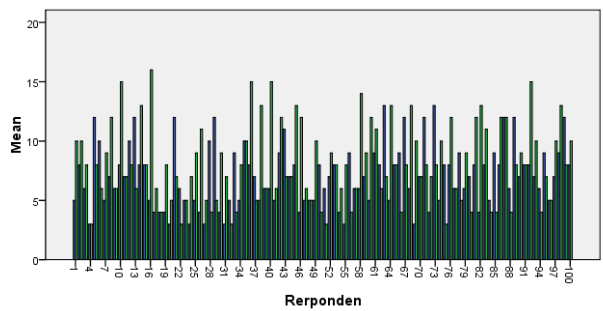

Gambar 1. Perbandingan frekuensi belanja

Gambaran umum data hasil kuisioner yang meliputi jumlah sampel, rata-rata, nilai minimum, nilai maksimum dan standar deviasi disajikan pada tabel 1 , sebagai berikut.

Tabel 1. Statistika Deskriptif

\begin{tabular}{|c|c|c|c|c|c|}
\hline & $\mathrm{N}$ & Minimum & Maximum & Mean & Std. Deviation \\
\hline $\begin{array}{l}\text { belanja_di_ } \\
\text { riteltradisional_Setelah } \\
\text { adany_Ritel_Moderen }\end{array}$ & 100 & 3 & 16 & 8.18 & 3.322 \\
\hline $\begin{array}{l}\text { belanja_di_- } \\
\text { riteltradisional_Sebelum_ } \\
\text { adanya_Ritel_Moderen } \\
\text { Valid N (listwise) }\end{array}$ & $\begin{array}{l}100 \\
100\end{array}$ & 3 & 13 & 7.07 & 2.614 \\
\hline
\end{tabular}

Sampel terdiri dari 100 orang, dari kecamatan Sumbawa yang diambil dengan metode sampel acak sederhana. Frekuensi jumlah terendah kunjungan warga kecamatan Sumbawa pada ritel tradisional sebelum adanya ritel moderen adalah 3 kali sedangkan frekuensi jumlah kunjungan tertinggi adalah 13 kali.

Setelah adanya ritel moderen beroprasi maka diperoleh Frekuensi jumlah terendah kunjungan warga kecamatan Sumbawa pada ritel tradisional sebelum adanya ritel moderen adalah 3 kali sedangkan frekuensi jumlah kunjungan tertinggi adalah 16 kali.

Secara umum, rata-rata frekuensi kunjungan pelangan pada ritel tradisional mengalami kenaikan setelah adanya ritel moderen beroprasi di kecamatan Sumbawa. Semula rataratanya sebanyak 7,07 menjadi 8,18. Nampaknya 
kenaikan nilai rata-rata ini menunjukkan bahwa jumlah kunjungan konsumen pada ritel tradisional lebih baik setelah adanya ritel moderen dari pada kondsisi sebelum ritel moderen. Namun, ini masih perlu dilakukan pengujian lebih lanjut.

Frekuensi jumlah kunjungan warga kecamatan Sumbawa pada ritel tradisional setelah adanya ritel moderen lebih bervariasi dibandingkan dengan kondisi sebelum adanya ritel moderen. Hal ini dapat ditunjukkan pada nilai standar deviasinya yang relatif lebih besar.

\section{Uji Normalitas}

Berdasarkan data pada hasil kuisioner yang telah disajikan pada gambar 1 akan dilakukan analisa perubahan jumlah konsumen pada ritel tradisional setelah adanya ritel moderen di kecamatan Sumbawa dengan analisa statistika dengan menggunakan SPSS. Terlebih dahulu data pada gambar 1 akan dianalis apakah berdistribusi normal atau tidak. Adapun outpun pengujian normalitas pada SPSS dapat dilihat pada tabel 1 sebagai berikut.

Tabel 2. Uji Normalitas

\begin{tabular}{|c|c|c|c|c|c|c|c|}
\hline & & \multicolumn{3}{|c|}{ Kolmogoror-Smimove } & \multicolumn{3}{|c|}{ Shapiro-Wilk } \\
\hline \multirow{2}{*}{\begin{tabular}{|l|} 
hasil \\
\end{tabular}} & 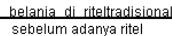 & Statistic & df & sia. & \begin{tabular}{|l|l} 
Statistic \\
\end{tabular} & & sia \\
\hline & $\begin{array}{l}\text { moderen } \\
\text { setelah adanyar mitel }\end{array}$ & $\begin{array}{l}.119 \\
122\end{array}$ & $\begin{array}{l}100 \\
100\end{array}$ & $\begin{array}{l}.001 \\
001\end{array}$ & $\begin{array}{l}.944 \\
956\end{array}$ & ${ }_{100}^{100}$ & .000 \\
\hline
\end{tabular}

Berdasarkan hasil output program SPSS, dikatakan data berdistribusi normal bila nilai sig (p) $>0,05$ dan data tidak normal bila nilai sig $(\mathrm{p})<$ 0,05 (Oktaviani \& Notobroto, 2014). Berdasarkan hasil output SPSS yang disajikan pada tabel 2, hasil uji normalitas data perubahan frekuensi belanja warga kecamatan Sumbawa pada ritel tradisional sebelum dan sesudah adanya ritel moderen, menunjukkan bahwa nilai sig, kurang dari 0,05 maka data tersebut tidak berdistribusi normal.

Karena data tersebut tidak berdisribusi normal maka untuk menggetahui perubahan frekuensi kunjungan warga kecamatan Sumbawa pada ritel tradisional stelah adanya ritel moderen di dikecamatan Sumbawa dapat menggunakan metode analisis statistika parametrik atau statistika nonparametrik (Kadir, 2015). Menggunakan Namun pada penelitin ini, peneliti menggunakan metode non-parametrik yaitu menggunakan uji tanda.

\section{Statistika Nonparametik (Uji Tanda)}

Kemudian dilakukan analisa terhadap data pada gambar 1 dengan pendekatan uji statistika nonparametrik menggunakan uji tanda, dimana output analisa yang dihasilkan SPSS dengan menggunakan uji tersebut hasilnya dapat dilihat pada tabel 2 dan tabel 3 sebagai berikut.
Tabel 2. Frekuensi

\begin{tabular}{|l|l|c|}
\hline \multicolumn{2}{|c|}{} & N \\
\hline \multirow{3}{*}{ Setelah - Sebelum } & Negative Differences $^{\mathrm{a}}$ & 31 \\
\cline { 2 - 3 } & Positive Differences $^{\mathrm{b}}$ & 51 \\
\cline { 2 - 3 } & Ties $^{\mathrm{c}}$ & 18 \\
\cline { 2 - 3 } & Total $^{2}$ & 100 \\
\hline \multicolumn{2}{|c|}{ a. Setelah < Sebelum } \\
\hline \multicolumn{2}{|c|}{ b. Setelah > Sebelum } \\
\hline \multicolumn{2}{|c|}{ c. Setelah $=$ Sebelum } \\
\hline
\end{tabular}

Pada tabel 2, Negative Differences atau selisih (negatif) antara frekuensi berbelanja warga kecamatan Sumbawa pada ritel tradisional setelah adanya ritel moderen dan sebelum adanya ritel moderen adalah 31 . Hal ini menunjukkan bahwa terdapat 31 orang dalam sebulan mengalami lebih dominan bebelanja pada ritel tradisional sebelum adanya ritel moderen.

Positive Differences atau selisih (positif) antara frekuensi berbelanja warga kecamatan Sumbawa pada ritel tradisional setelah adanya ritel moderen dan sebelum adanya ritel moderen adalah 51. Ini menunjukkan bahwa terdapat 51 orang dalam sebulan mengalami lebih dominan bebelanja pada ritel tradisional setelah adanya ritel moderen.

Ties adalah kesamaan antara frekuensi jumlah kunjungan warga kecamatan Sumbawa pada ritel tradisional sebelum dan setelah adanya ritel moderen adalah 18 kal. Ini menunjukkan terdapat 18 kali dalam sebulan yang jumlah jumlah kunjungan warga kecamatan Sumbawa pada ritel tradisional tidak mengalami perubahan setelah adanya ritel moderen.

Tabel 3. Test Statistics

\begin{tabular}{|c|c|}
\hline & Setelah - Sebelum \\
\hline Z & $-2,098$ \\
\hline Asymp. Sig. (2-tailed) &, 036 \\
\hline a. Sign Test \\
\hline
\end{tabular}

Pada tabel 3, Dengan menggunakan pendekatan Pvalue dimana nilai sig (P-value) yang diperoleh adalah $\alpha(0,05)>0,036$ (2-tailed) maka keputusannya adalah $\mathrm{H}_{0}$ ditolak (Maryadi, 2020). Dengan demikian dapat disimpulkan bahwa cukup bukti untuk mendukung pernyataan bahwa Keberadaan ritel moderen di kecamatan Sumbawa menurunkan jumlan pelangan yang belanja di ritel tradisional.

\section{PENUTUP}

\section{Kesimpulan}

Berdasarkan uji statistik nonparametrik menunjukkan bahwa cukup bukti untuk mendukung pernyataan bahwa Keberadaan ritel moderen di kecamatan Sumbawa menurunkan jumlah pelanggan yang belanja di ritel tradisional. Oleh karena itu perlu adanya strategi bagi pelaku usaha ritel tradisional dan pemerintah untuk dapat 
meningkatkan inovasi bagi ritel tradisional agar tidak kalahbersaing dengan usaha ritel moderen.

\section{UCAPAN TERMAKASIH}

Pada kesempatan ini, tim peneliti menyampaikan terima kasih kepada Ditlitabmas Dirjen Dikti Kementerian Pendidikan dan Kebudayaan yang telah sepenuhnya mendanai penelitian ini dalam skema Penelitian Dosen Pemula (PDP). Semoga penelitian ini dapat bermanfaat.

\section{REFERENSI}

Amri, F., Jibrail, A., \& Surwadi, D. (2017). Analisis Perbandingan Jumlah Laba Pedagang Kelontong Setelah Berdirinya Alfamart (Studi Kasus Di Kecamatan Sumbawa). 2(2), 47-52.

Andespa, N. (2016). Meningkatkan pertumbuhan nasabah bank syariah: mendukung pembiayaan promosi, pendidikan dan pelatihan. Maqdis: Jurnal Kajian Ekonomi Islam, $\quad$ l(2), 171-188. http://journal.febi.uinib.ac.id/index.php/maqd is/article/view/44

Budiani, P., EP, A., \& Widiartanto. (2015). Pengaruh Atribut Toko dan Fashion Involvement terhadap Keputusan Pembelian Konsumen (Studi Kasus Pada Matahari Department Store Paragon Mall Semarang). Diponegoro Journal Of Social And Political of Science, 37, 1-10. https://doi.org/10.12816/0013114

Hermanto, K., \& Suarantalla, R. (2020). Analisis Minat Belanja Mahasiswa Teknik Industri UTS pada Ritel Tradisional dengan Adanya Ritel Moderen. 112, 296-302.

Kadir. (2015). Statistika Terapan: Konsep, Contoh dan Analisis Data dengan Program
SPSS/Lisrel dalam Penelitian (Octiviena (ed.); 2nd ed.). RajaGrafindo Persada.

Maryadi. (2020). Membandingkan Hasil Uji Statistika Parametrik dan Nonparametrik ( Studi Kasus: Pelaksanaan Kebijakan Pengendalian Dana Idle Pemerintah Daerah ). Jurnal Of Applied Managerial Accounting, 4(1), 142-149.

Oktaviani, M. A., \& Notobroto, H. B. (2014). Perbandingan Tingkat Konsistensi Normalitas Distribusi Metode KolmogorovSmirnov, Lilliefors, Shapiro-Wilk, dan Skewness-Kurtosis. Jurnal Biometrika Dan Kependudukan, 3(2), 127-135. http://journal.unair.ac.id/downloadfullpapers-biometrikd8bc041810full.pdf

Pradana, M., \& Reventiary, A. (2016). Pengaruh Atribut Produk Terhadap Keputusan Pembelian Sepatu Merek Customade (Studi di Merek Dagang Customade Indonesia). Jurnal Manajemen, 6(1), 1-10.

Rusno. (2008). Dampak Pesatnya Mini Market Waralaba Terhadap Usaha Kecil (Jenis Ritel). Jurnal Ekonomi Modernisasi, 4(3), 194-207.

http://ejournal.unikama.ac.id/index.php/JEK $\mathrm{O} /$ article/view/235

Sihombing, E. Y., \& Hidayat, P. (2013). Analisis Dampak Kehadiran Ritel Modern Terhadap Ritel Tradisonal di Kota Medan Studi Kasus Kehadiran Ritel Indomaret di Empat Kecamatan Kota Medan. Jurnal Ekonomi Dan Keuangan, 1(4), 74-84.

Utomo, T. J. (2011). Persaingan Bisnis Ritel: Tradisional vs Modern (The Competition of Retail Business: Traditional vs Modern). Fokus Ekonomi, 6(1), 122-133. 